\title{
Pemanfaatan Sistem Informasi Pada Usaha Kecil Menengah Untuk Pencatatan dan Pelaporan Transaksi Penjualan
}

\author{
Yulius Harjoseputro*1, Thomas Adi Purnomo Sidhi² \\ ${ }^{1,2}$ Program Studi Informatika, Fakultas Teknologi Indusri, Universitas Atma Jaya Yogyakarta \\ *e-mail: yulius.harjoseputro@uajy.ac.id¹, thomas.adi.ps@uajy.ac.id²
}

\begin{abstract}
The use of technology, especially information systems, has recently become quite popular among small and medium enterprises (SMEs). There have been many uses of information systems used in various kinds of SMEs in Indonesia. One of the most frequently used uses is to assist in managing transactions in an SME. Managing transactions in an SME business provides many advantages, including providing certainty for transaction data collection, making it easier to prove income as tax reports, providing convenience in managing store financial reports. Iron Shop and Central Building has been around for about ten years. Since this shop founded, all sales and purchases are still carried out by notes and manually calculated every day. This information system has successfully built so that in addition to helping solve all the problems that exist in the Iron Shop and Central Yogyakarta Building, it also provides advantages in transaction efficiency and transaction validity.
\end{abstract}

Keywords: SMEs, transactions, retailers, information systems

\begin{abstract}
Abstrak
Pemanfaatan teknologi khususnya sistem informasi belakangan ini menjadi cukup popular di kalangan usaha kecil menengah (UKM). Sudah banyak pemanfaatan sistem informasi yang digunakan di berbagai macam UKM di Indonesia. Salah satu pemanfaatan yang sering digunakan adalah untuk membantu dalam mengelola transaksi di suatu UKM. Pengelolaan transaksi pada usaha retailer atau UKM secara digital memberikan banyak keunggulan, diantaranya adalah memberikan kepastian pendataan transaksi, mempermudah pembuktian pemasukan sebagai laporan pajak, memberikan kenyamanan didalam mengelola laporan keuangan toko. Toko Besi dan Bangunan Central sudah berdiri kurang lebih 10 tahun. Sejak toko ini berdiri, semua transaksi penjualan dan pembelian masih dilakukan dengan nota dan secara manual dihitung setiap hari. Sistem Informasi ini telah berhasil dibangun sehingga selain dapat membantu menyelesaikan semua permasalahan yang ada pada Toko Besi dan Bangunan Central Yogyakarta, juga memberikan kelebihan efisiensi transaksi dan keabsahan transaksi.
\end{abstract}

Kata kunci: UKM, transaksi, retailer, sistem informasi

\section{PENDAHULUAN}

Usaha Kecil Menengah (UKM) di Indonesia merupakan salah satu harapan dalam menutup kesenjangan pertumbuhan ekonomi antara Eropa dan Asia pada tahun 2030. Selain itu, hal ini juga menjadi sektor yang penting dan besar kontribusinya dalam mewujudkan sasaran-sasaran pembangunan ekonomi nasional, seperti pertumbuhan ekonomi, kesempatan kerja, peningkatan devisa negara, dan pembangunan ekonomi daerah (Sinarwati, Sujana, Nyoman, \& Herawati, 2019). Dengan demikian, dalam situasi seperti itu, pentingnya Sistem Informasi Transaksi dan Pengelolaan Toko terungkap. (Nandan, 2010) dalam makalahnya menyatakan peran penting dari informasi sistem informasi pencatatan dan pelaporan transaksi untuk memantau dan mengendalikan kegiatan UKM. Dia mengatakan UKM membutuhkan Sistem informasi yang memadai dan canggih untuk mengelola efisiensi biaya dan untuk meningkatkan nilai-nilai penting dalam UKM, setinggi kebutuhan dari perusahaan besar atau perusahaan multinasional. Sayangnya, kepentingan ini sering dilupakan oleh UKM sampai mereka diminta oleh pihak atau lembaga hukum tertentu untuk menunjukkan jurnal atau laporan mereka sebagai kondisi tujuan tertentu (mis. Untuk kredit atau investasi modal). Pembangunan UKM sebagai badan usaha ditujukan pada penguatan dan perluasan bisnis usaha, peningkatan mutu, sumber daya, pengelola dan produk yang dihasilkan, termasuk kewirausahaan dan profesionalisme UKM. Selain itu UKM dapat berkinerja dengan baik, mandiri, dan kompetitif, UKM diharapkan mampu menjadi badan 
usaha yang mampu menopang perekonomian (Putu \& Aditya, 2015). Disamping permasalahan diatas, UMKM di Indonesia merupakan salah satu jenis usaha yang memiliki banyak peminat, namun masih sedikit UMKM yang menerapkan TI diproses bisnis mereka (Martinus Maslim, Adithama, \& Nugroho, 2020).

Kegagalan untuk memahami kebutuhan teknik dan sistem informasi manajemen yang terdeteksi disebabkan oleh kurangnya pengetahuan tentang cara melakukannya. "Bagaimana cara merekam kegiatan transaksi? Bagaimana cara mengukur nilai barang? Bagaimana cara membuat anggaran? Bagaimana cara menghitung penyusutan? "Pertanyaan-pertanyaan itu sering diajukan kepada pemilik atau praktisi UKM. Faktanya, UKM hanya sering memiliki laporan kas masuk dan arus kas keluar saja tanpa memperhatikan dari mana uang itu berasal atau untuk apa. Selain itu hambatan-hambatan didalam pertumbuhan UKM adalah perbedaan wilayah dan keterbatasan modal kerja atau investasi, pemasalahan-permasalahan ini secara langsung maupun tidak dapat teratasi dengan penerapan teknologi pada proses bisnis yang dijalankan UKM tersebut (Firdaus \& Widyasastrena, 2017).

Mempertimbangkan masalah itu, penulis bermaksud menggunakan keunggulan teknologi untuk membantu UKM INDONESIA mengatasi teknik dan sistem keuangan manajemen mereka terlebih pada sumber informasi yang tidak jelas (Harjoseputro \& Herawati, 2018). Penggunaan teknologi sebagai bantuan yang dipandang cocok untuk UKM INDONESIA, karena data menunjukkan bahwa sebagian besar INDONESIA didominasi oleh tenaga kerja muda dan basis konsumen lebih dari 646 juta orang (UKM INDONESIA: Apakah Anda Mengubah Masa Depan ?, 2019). Selain itu teknologi dapat mengurangi biaya yang dikeluarkan baik untuk barang maupun jasa serta dapat meningkatkan kepuasan konsumen melalui kemudahan dalam pencarian maupun fungsionalitas teknologi yang lain (Nugraha, 2016). Selama pengabdian ini, sistem sistem informasi pencatatan dan pelaporan transaksi pada Toko Besi dan Bangunan Central untuk penjualan dan catatan kegiatan bisnis perangkat lunak dikembangkan. Seperti yang diungkapkan oleh hasil, peneliti berharap perangkat lunak mobile yang sedang dikembangkan dapat membantu banyak UKM. Selain itu, peneliti juga berharap dapat meningkatkan kesadaran akan pentingnya sistem keuangan manajemen untuk UKM.

Proses bisnis yang dijalankan Toko Besi dan Bangunan Central merupakan proses bisnis umum UKM Toko Retail. Pembeli melakukan transaksi pembelian terhadap barang ataupun jasa dan melakukan pembayaran secara tunai. Pembelian yang dilakukan pelanggan dicatat secara manual dan tidak ada pendataan barang-barang yang sudah terjual. Hal ini menjadi permasalahan pokok bagi usaha ini, dikarenakan tidak adanya pendataan transaksi yang sudah dilakukan diusaha ini. Penerapan TI sudah dilakukan dalam berbagai studi kasus dan terbukti dapat meningkatkan potensi UKM dan meningkatkan perekonomian UKM dan daerah sekitarnya (Jonathan \& Lestari, 2015). Pemanfaatan teknologi informasi dan sistem informasi pada suatu organisasi dapat membantu organisasi untuk mencapai tujuan dengan maksimal (Mumtahana, Hani Atun, Nita \& Tito, 2017).

Permasalahan yang juga timbul adalah bukti pelaporan pajak maupun keabsahan pembelian. Hal ini disebabkan nota yang ada tidak berupa computer generated faktur namun masih manual. Sedangkan untuk perpajakan, Toko Besi dan Bangunan Central masih melakukan pelaporan yang tidak detail sehingga terkadang taksiran petugas pajak menjadi tidak sesuai dengan keadaan sesungguhnya. Kebutuhan dana untuk bantuan modal juga merupakan salah satu faktor yang membutuhkan pencatatan yang baik dan pelaporan dikarenakan hal ini merupakan penunjang sukses tidaknya sebuah pinjaman modal disetujui (Rifani \& Aini, 2016). Permasalahan lain yang timbul berikutnya adalah kemungkinan adanya tindakan kecurangan yang dilakukan karyawan dikarenakan semua transaksi masih manual. Proses pengolahan data yang dilakukan secara manual, memungkinkan terjadi kesalahan dalam pencatatan (Adithama, Maslim, Harjoseputro, \& Suharno, 2017). Hal ini terdeteksi saat adanya pembelian dalam jumlah banyak yang transaksinya tidak sesuai dengan harga dan jumlah barang yang didapatkan pelanggan. Hal ini merugikan baik pelanggan maupun nama baik penjual. 
Tabel 1. Solusi dan Target Luaran

\begin{tabular}{|c|c|c|}
\hline Permasalahan & Solusi & Target Luaran \\
\hline $\begin{array}{l}\text { Permasalahan dalam } \\
\text { pengelolaan terhadap } \\
\text { usaha mitra dan } \\
\text { pengelolaaan stok } \\
\text { dengan pemanfataan } \\
\text { teknologi informasi }\end{array}$ & $\begin{array}{l}\text { Membangun sistem } \\
\text { informasi pencatatan dan } \\
\text { pelaporan transaksi atau } \\
\text { Aplikasi Point Of Sale (POS) } \\
\text { - Pelatihan untuk pengelola } \\
\text { aplikasi yang akan } \\
\text { mengoperasikannya }\end{array}$ & $\begin{array}{l}\text { - Satu (1) sistem informasi } \\
\text { pencatatan dan pelaporan } \\
\text { transaksi atau Aplikasi Point } \\
\text { Of Sale (POS) } \\
\text { - Memiliki minimal satu (1) } \\
\text { administrator aplikasi yang } \\
\text { akan mengelola aplikasi ini }\end{array}$ \\
\hline
\end{tabular}

\section{METODE}

Berdasarkan permasalahan yang telah disepakati dengan pihak mitra, maka solusi yang ditentukan dalam pengabdian ini adalah untuk membantu aspek manajemen dari mitra, khususnya dengan memanfaatkan teknologi informasi, maka akan dibuatkan Sistem Informasi Pencatatan dan Pelaporan Transaksi Penjualan. Selain itu, juga akan diberikan pelatihan terhadap pengelola mitra untuk dilatih dalam mengoperasikan aplikasi ini.

Adapun tahapan-tahapan yang akan dilakukan untuk mengatasi permasalahan Toko Besi dan Bangunan Central adalah sebagai berikut:

a. Tahap Persiapan

Dimana di dalam tahap persiapan ini, terdapat 2 hal yang dilakukan, yakni (1) Identifikasi kebutuhan mengenai hal-hal apa saja yang menjadi kebutuhan pengguna dalam mengelola usahanya (2) Identifikasi kemampuan penggunaan baik aplikasi, internet dan komputer dari para pengelola mitra.

b. Tahap Pelaksanaan

Pada tahap pelaksanaan ini, terdapat 2 hal juga yang dilakukan dalam pengabdian ini, diantaranya :

1) Pembangunan Sistem Informasi Pencatatan dan Pelaporan Transaksi

Aplikasi yang akan dibuat ini memiliki beberapa fungsional diantaranya adalah pengelolaan pengguna atau pegawai, pengelolaan role, pengelolaan barang, pengelolaan transaksi, pengelolaan pembayaran, dan pembuatan beberapa laporan.

2) Melaksanakan pelatihan administrator aplikasi dan pegawai dalam mengisi mengoperasikan aplikasi ini

c. Tahap Evaluasi

Pada tahap ini akan dilakukan evaluasi terhadap hasil karya yang dihasilkan dari pengabdian ini, dimana evaluasi ini dilakukan setelah sistem informasi yang dibuat tersebut dipublikasikan

Solusi ini tidak hanya akan menyelesaikan permasalahan. Solusi ini akan memberikan dampak positif bagi mitra. Salah satu dampak positif yang terjadi adalah kemampuan untuk dapat memonitoring secara online kapanpun dan dimanapun transaksi operasional yang akan dilakukan. Kemampuan ini memberikan kontribusi terhadap kedisiplinan dan pencapaian kinerja karyawan yang lebih baik. Kinerja karyawan yang lebih baik tentunya akan meningkatkan pelayanan terhadap pelanggan dan pada akhirnya meningkatkan tingkat kepuasan pelanggan.

\section{HASIL DAN PEMBAHASAN}

A. Pembuatan Sistem Informasi Pencatatan dan Pelaporan Transaksi Pada Toko Besi dan Bangunan Central Yogyakarta

Pada Pembuatan sistem informasi ini dimulai pada bulan September 2019 dengan diawali dengan proses pengumpulan data terlebih dahulu serta mengumpulkan informasi mengenai kebutuhan apa saja yang dibutuhkan oleh pihak Toko Besi dan Bangunan Central Yogyakarta ini. 
Setelah itu, proses yang selanjutnya yang dilakukan adalah pembuatan antarmuka atau prototype dari sistem informasi ini baik Low Fidelity Prototype maupun High Fidelity Prototype. Hal terakhir yang dilakukan di tahap peracangan ini adalah perancangan databasenya, dalam hal ini menghasilkan rancangan Entitas Relationshop Diagram (ERD) yang akan digunakan dalam pembangunan sistem informasi ini.

Berdasarkan hasil dari perancangan yang telah dikerjakan tersebut lalu mulai dibangun sebuah sistem informasi pencatatan dan pelaporan transaksi pada toko besi dan bangunan central Yogyakarta berbasis desktop. Pada sistem tersebut menampilkan beberapa informasi dan fungsi, diantaranya fungsi login, fungsi pengelolaan, fungsi transaksi pembayaran, dan cetak nota, yang ditampilkan seperti gambar berikut :

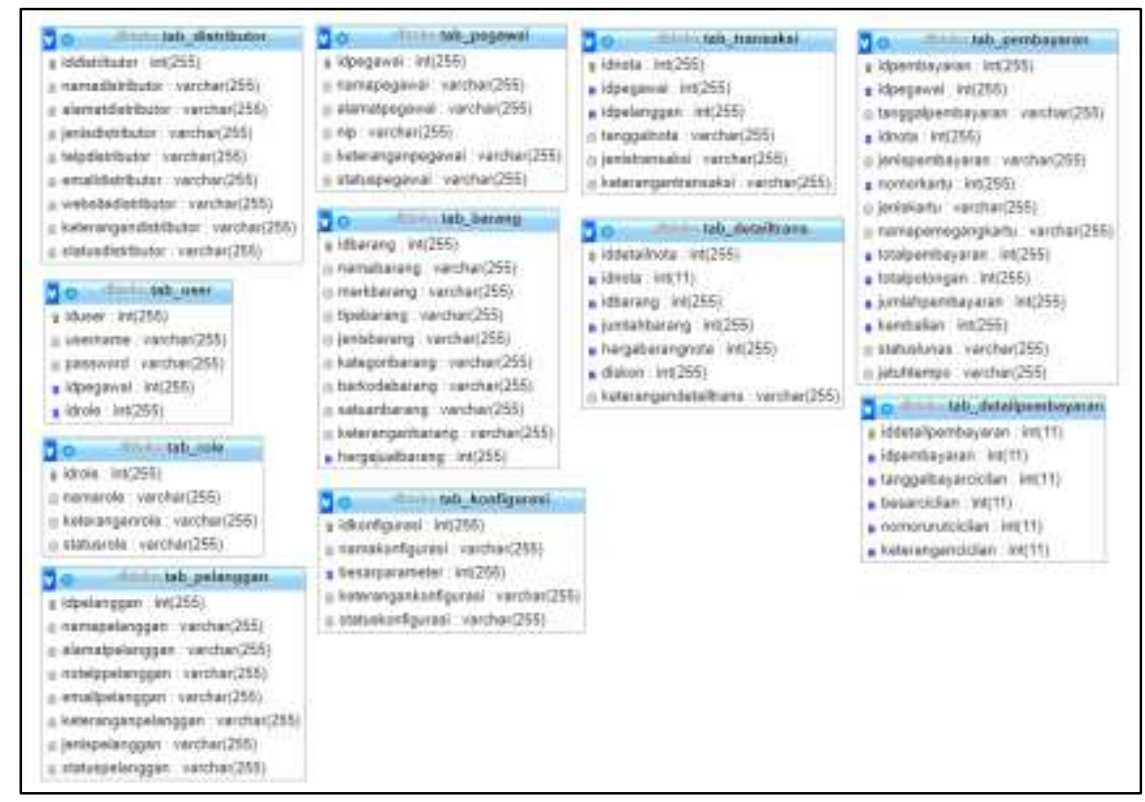

Gambar 1. Database Sistem Informasi Yang Dibuat

Pada gambar 1 diatas merupakan skema database yang digunakan di dalam sistem informasi dalam pengabdian ini. Berdasarkan gambar 1 diatas terdapat 11 tabel yang digunakan dalam pengabdian ini, diantaranya adalah tabel distributor, tabel user, tabel role, tabel pelanggan, tabel pegawai, tabel barang, tabel konfigurasi, tabel transaksi, tabel detail transaksi, tabel pembayaran, dan tabel detail pembayaran.

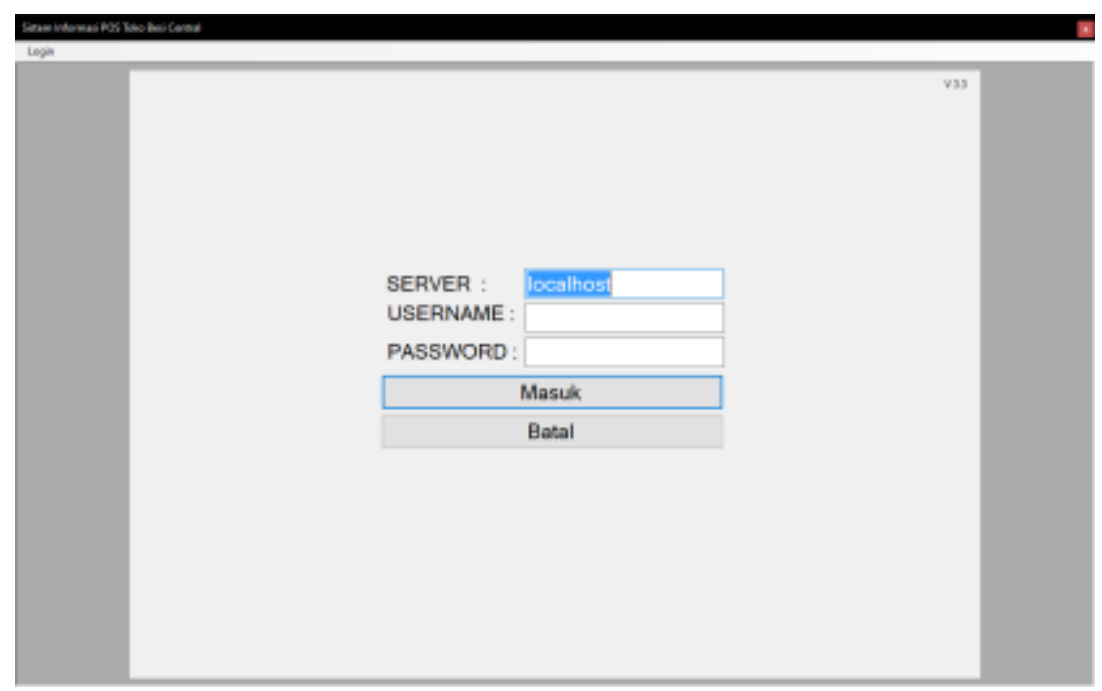

Gambar 2. Tampilan Halaman Login 
Pada gambar 2 diatas merupakan tampilan untuk halaman login, dimana halaman login ini digunakan sebelum user mengakses fungsi-fungsi yang terdapat dalam sistem ini. Berdasarkan gambar tersebut terdapat tiga inputan yang harus diisikan oleh pengguna, yakni server, username dan password. Dari ketiga tersebut setelah terisi semua, maka akan dilakukan pengecekan terlebih dahulu mengenai hak login dan role sebelum memasuki sistem, salah satunya seperti yang tertampil pada gambar 3 berikut.

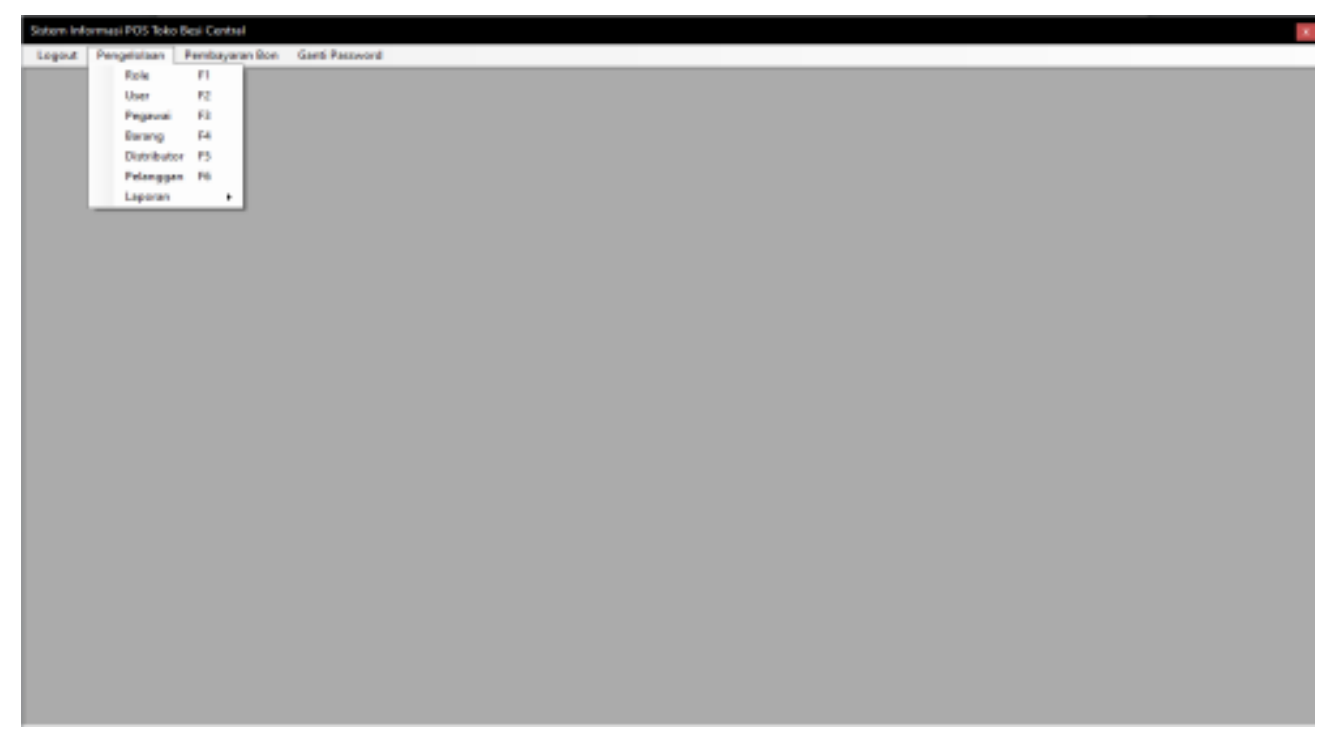

Gambar 3. Tampilan Halaman Pengelolaan

Pada gambar 3 diatas merupakan tampilan halaman pengelolaan yang digunakan oleh pengguna setelah memasukkan username dan password sesuai dengan rolenya. Pada halaman ini berisi fungsi-fungsi yang digunakan oleh role : administrator, diantaranya adalah pengelolaan role, pengelolaan user, pengelolaan pegawai, pengelolaan barang, pengelolaan distributor, pengelolaan pelanggan dan laporan. Dalam hal ini pengguna hanya tinggal memilih fungsi mana yang dinginkan untuk diakses dengan cara klik pada menu fungsi yang diinginkan.

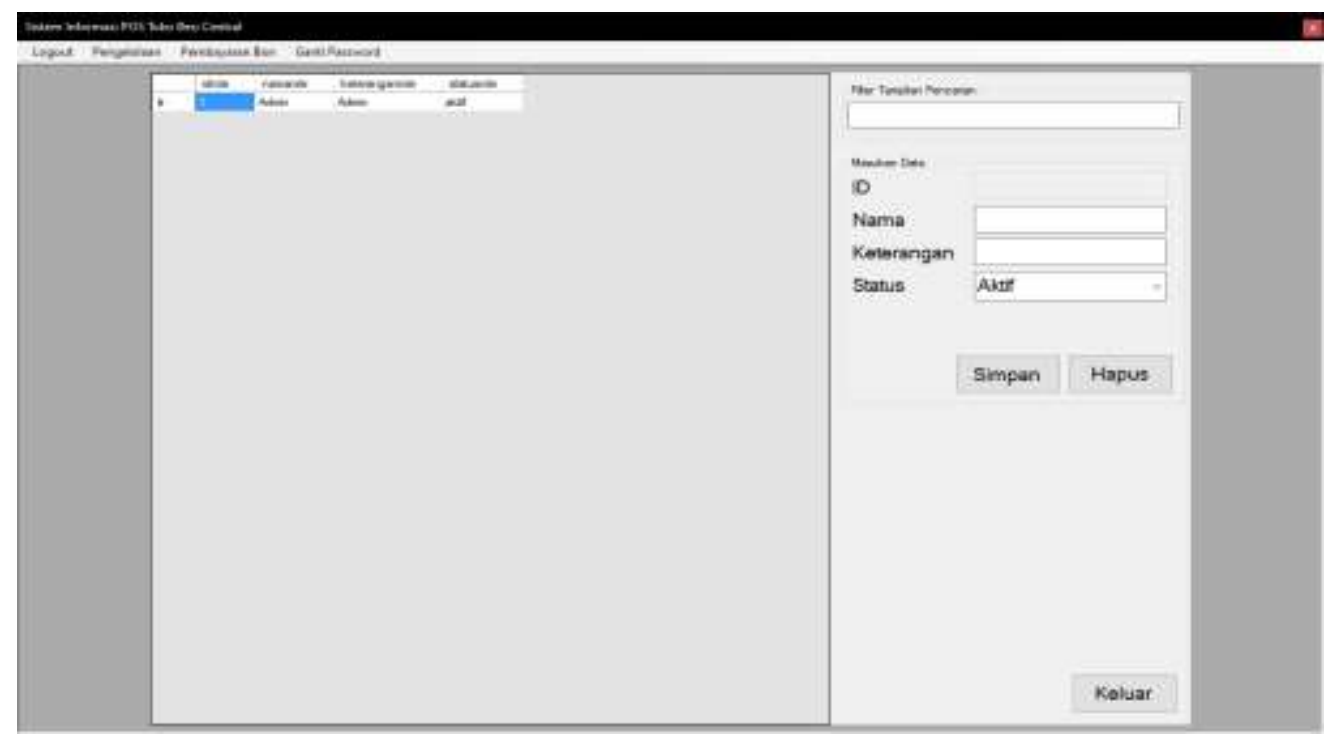

Gambar 4. Tampilan Halaman Pengelolaan Role

Pada gambar 4 merupakan bagian dari fungsi yang ada pada gambar 3 diatas yakni adalah fungsi pengelolaan Role. Dimana pada tampilan ini, pengguna yang bisa mengakses adalah pengguna yang memiliki role sebagai administrator. Dimana pengguna dapat menambah, melihat, 
mengedit dan menghapus role yang diinginkan. Pada halaman ini memiliki 3 buah inputan yang harus diinputkan, yakni nama, keterangan dan status. Status dalam hal ini untuk menentukan rolenya aktif atau tidak aktif.

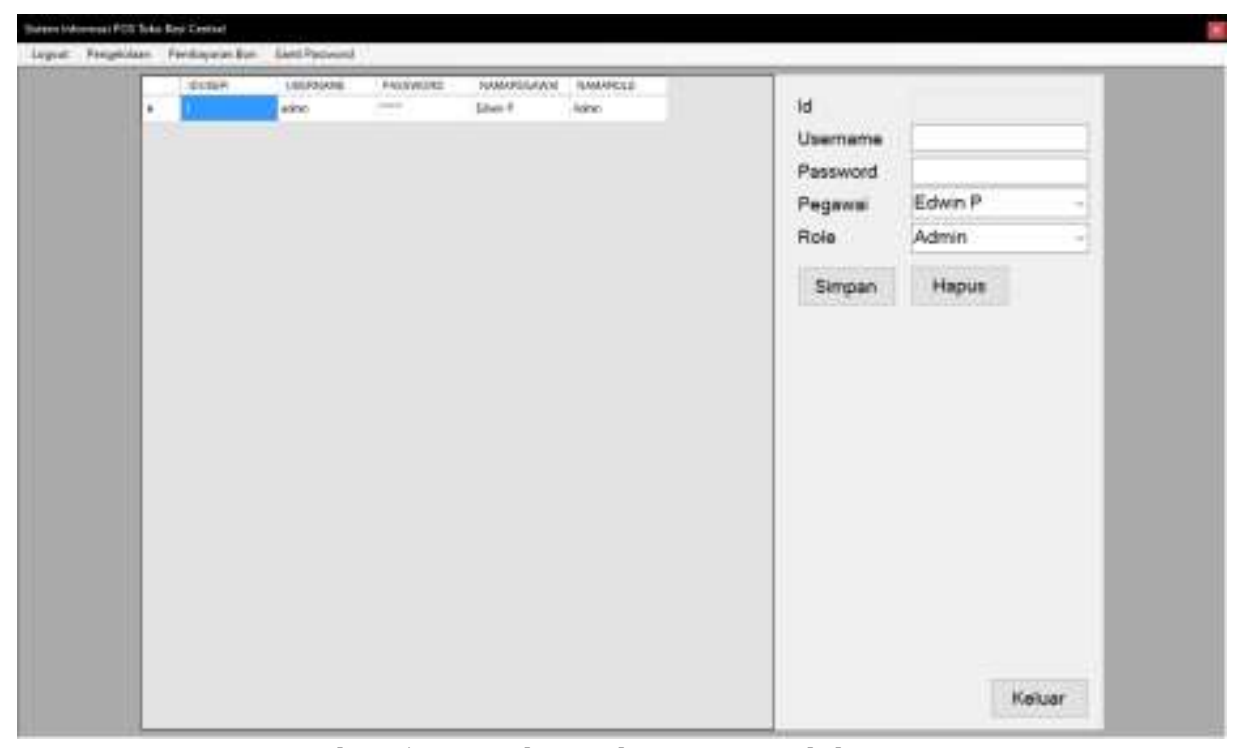

Gambar 5. Tampilan Halaman Pengelolaan User

Sedangkan pada gambar 5 berikut merupakan tampilan untuk halaman pengelolaan user. Sama dengan sebelumnya bahwa halaman ini digunakan juga oleh administrator untuk mengelola usernya yang akan bisa menggunakan sistem tersebut. Dalam pengelolaan ini terdapat 4 buah inputan yang harus dimasukkan user yakni username, password, pegawai dan role. Pada pengelolaan ini juga dapat melakukan beberapa fungsi diantaranya menambah, mengedit, melihat, dan menghapus user.

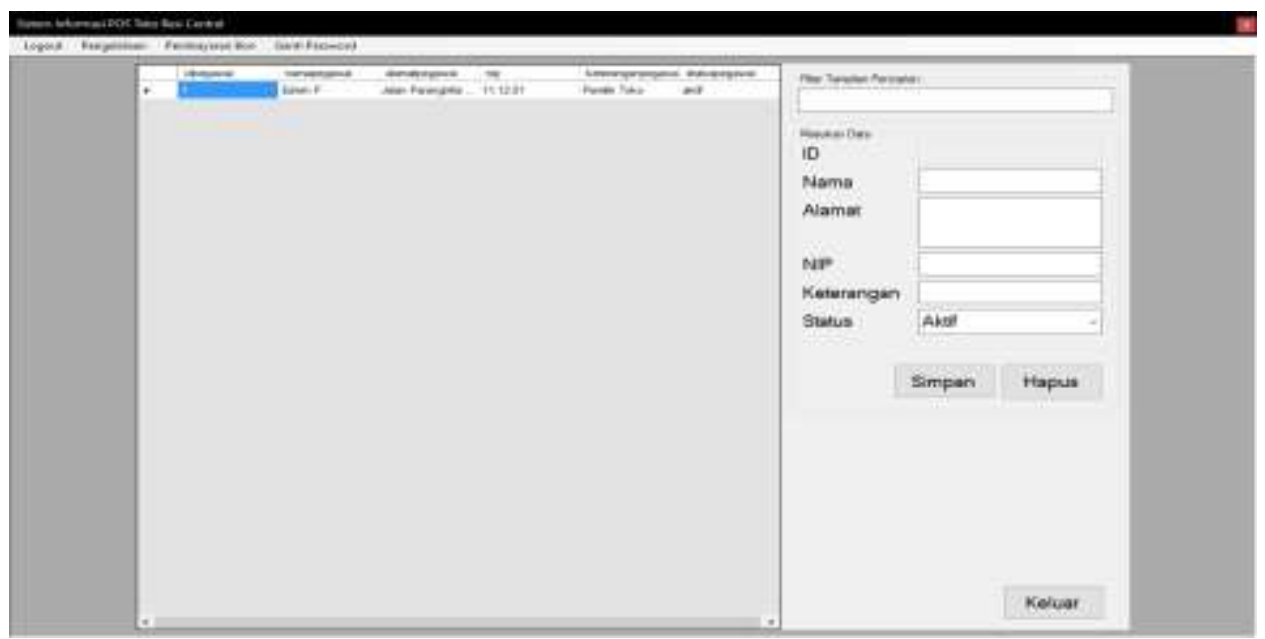

Gambar 6. Tampilan Halaman Pengelolaan Pegawai

Lalu pada gambar 6 berikut merupakan tampilan untuk halaman pengelolaan pegawai. Sama dengan sebelumnya bahwa halaman ini digunakan juga oleh administrator untuk mengelola pegawainya yang akan bisa menggunakan sistem tersebut. Dalam pengelolaan ini terdapat 5 buah inputan yang harus dimasukkan user yakni nama, alamat, nip, keterangan, dan status. Pada pengelolaan ini juga dapat melakukan beberapa fungsi diantaranya menambah, mengedit, melihat, dan menghapus user. Status dalam hal ini untuk menentukan rolenya aktif atau tidak aktif. 


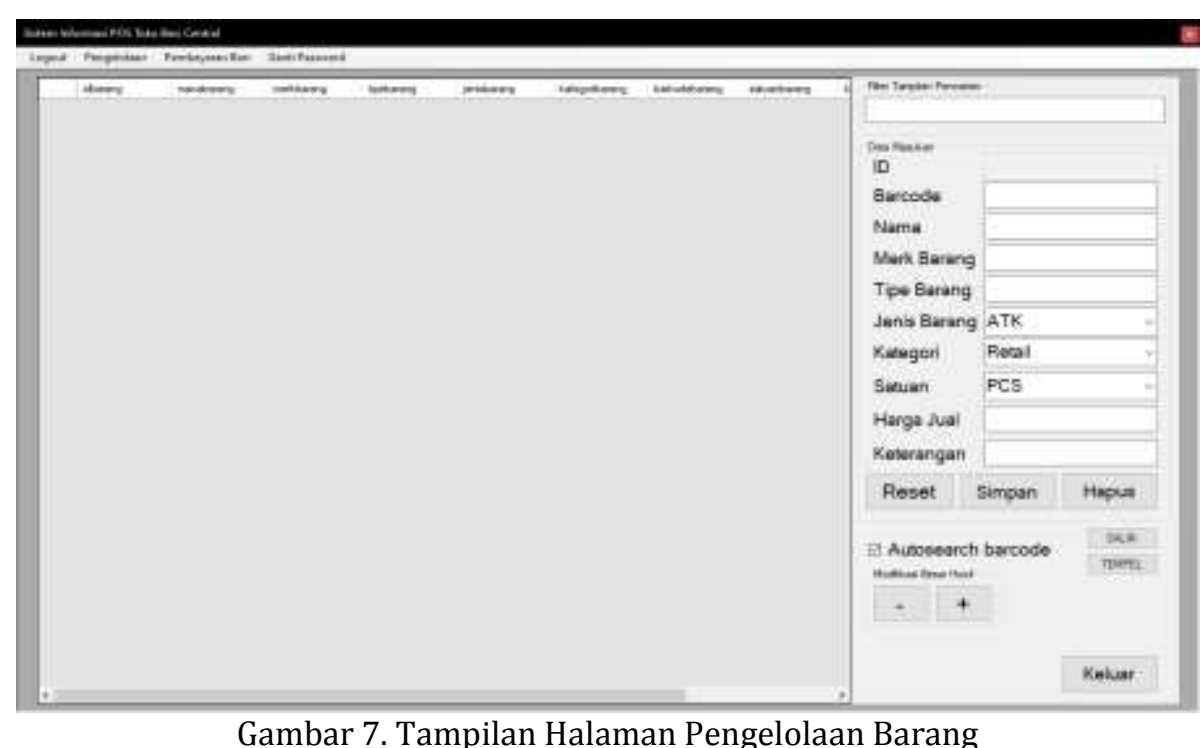

Berdasarkan gambar 7 berikut merupakan tampilan untuk halaman pengelolaan barang. Halaman ini nantinya akan dikelola oleh administrator. Pada tampilan ini terlihat 9 inputan yang harus diinputkan oleh user, diantaranya adalah barcode, nama, merk barang, tipe barang, jenis barang, kategori, satuan, harga jual dan keterangan. Setelah user mengisikan semua inputan, lalu user dapat memilih 3 button yang tersedia, yakni button reset yang berguna untuk mereset inputan user dan menjadikan seluruh inputan menjadi kosong kembali, lalu ada button simpan yang berguna untuk menyimpan data yang telah diinputkan user, dan yang terakhir adalah button hapus yang berguna untuk menghapus data yang dipilih oleh user. Selain itu pada tampilan tersebut juga tersedia fasilitas pencarian yang terletak di kanan atas, dimana user dapat memilih apakah pencarian tersebut otomatis atau tidak.

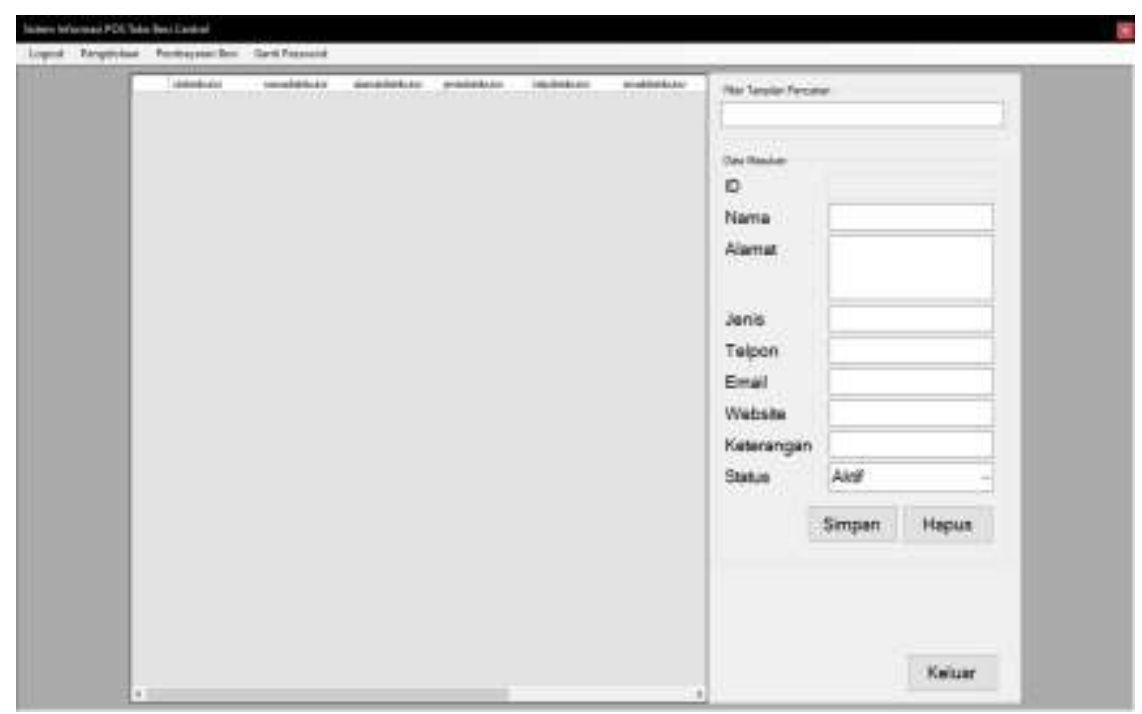

Gambar 8. Tampilan Halaman Pengelolaan Distributor

Selanjutnya masih dari pengelolaan yang dikelola oleh administrator, yakni halaman pengelolaan distributor yang ditampilkan pada gambar 8. Pada halaman tersebut, seorang admin masih harus menginputkan beberapa inputan diantaranya adalah nama, alamat, jenis, telpon, email, website, keterangan dan status dari distributornya. Selain itu terdapat juga 2 buah button yakni button simpan dan hapus yang kegunaanya adalah untuk menyimpan data yang diinputkan oleh user, dan untuk menghapus data yang dipilih oleh user. 


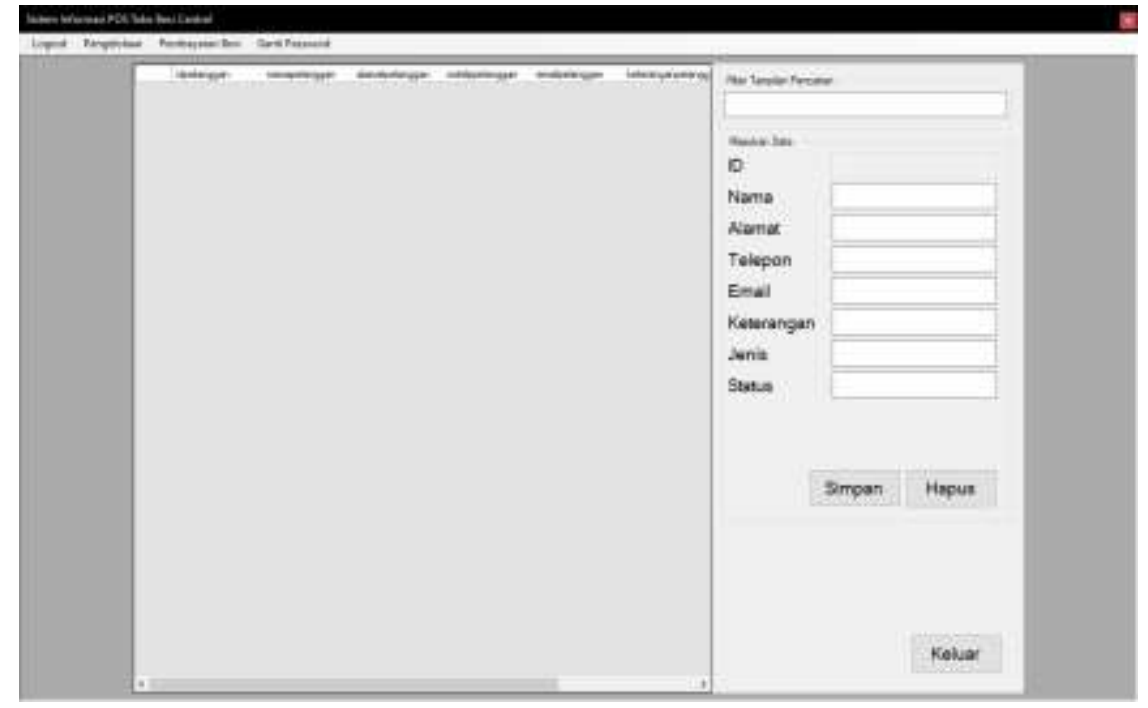

Gambar 9. Tampilan Halaman Pengelolaan Pelanggan

Pada gambar 9 merupakan tampilan halaman pengelolaan pelanggan yang masih sama teteap dikelola oleh seorang administrator. Pada halaman tersebut, seorang admin masih harus menginputkan beberapa inputan diantaranya adalah nama, alamat, telepon, email, keterangan, jenis dan status dari pelanggan tersebut. Selain itu terdapat juga 2 buah button yakni button simpan dan hapus yang kegunaanya adalah untuk menyimpan data yang diinputkan oleh user, dan untuk menghapus data yang dipilih oleh user.

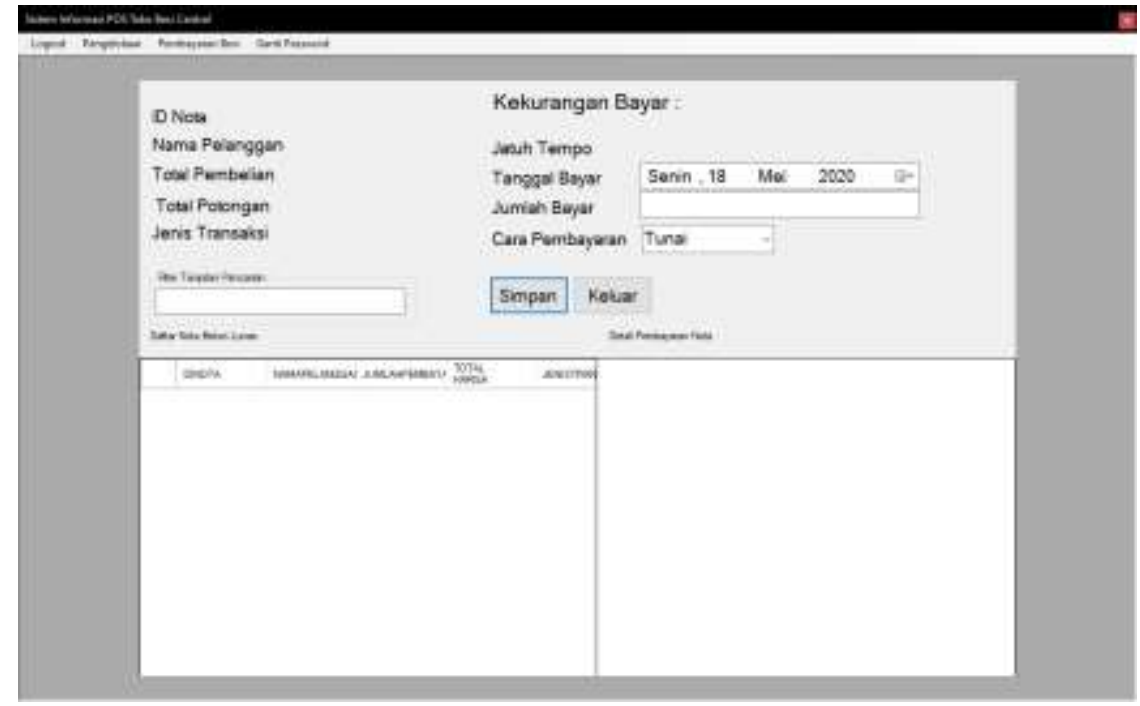

Gambar 10. Tampilan Halaman Pengelolaan Pembayaran Bon

Selanjutnya, pada gambar 10 merupakan tampilan halaman pengelolaan pembayaran bon. Dimana pada gambar tersebut terlihat bahwa user akan melakukan pembayaran bon yang dilakukan oleh pelanggan. Pada halaman tersebut terdapat tanggal bayar yang defaultnya adalah tanggal sekarang pada saatu sistem tersebut digunakan. User dapat memilih apakah pembayarannya itu tunai atau tidak. Jika semua inputan sudah dipenuhi, maka user dapat memilih button simpan untuk menyimpan data pembayaran bon tersebut.

Sedangkan pada gambar 11 merupakan tampilan untuk halaman pengelolaan password, dimana user dapat mengganti secara mandiri password yang dimiliki dengan terlebih dahulu memasukkan password lamanya sebelum menuliskan password baru dan ketik ulang password baru. Setelah itu, user dapat menekan tombol "Ganti Password" untuk melakukan penyimpanan 
terhadap password barunya. Pada gambar tersebut juga terdapat button "Keluar" yang berguna untuk keluar dari form tersebut dan membatalkan penggantian password.

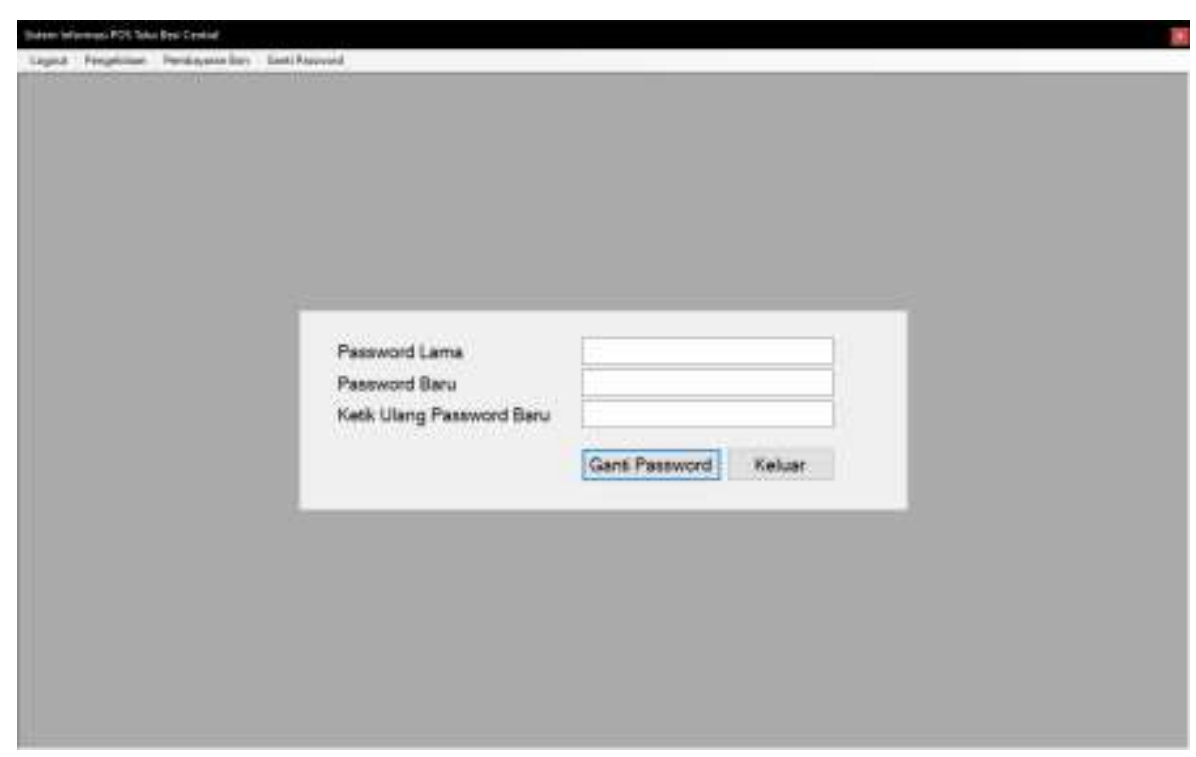

Gambar 11. Tampilan Halaman Pengelolaan Password

Lalu , pada gambar 12 berikut merupakan tampilan untuk halaman pengelolaan transaksi yang dilakukan oleh pegawai atau kasir dalam hal ini.

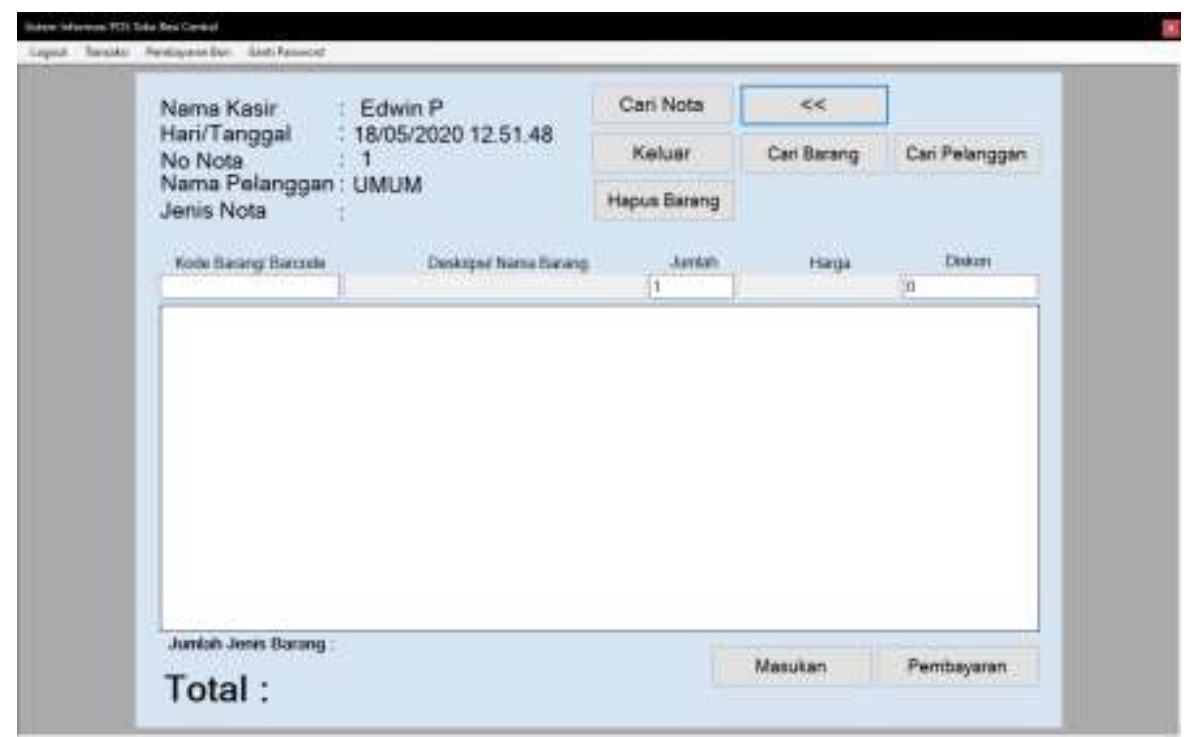

Gambar 12. Tampilan Halaman Pengelolaan Transaksi

Dimana pegawai tersebut nantinya akan melakukan penginputan barang yang dibeli oleh pelanggan dengan menekan tombol "Cari Barang" sehingga akan muncul pada gambar 13 berikut. Pada gambar 13 tersebut, user dapat memasukkan barang yang dibeli user dengan memasukkan tipe barang atau menginputkan kata kunci dari barang tersebut, otomatis barang dicari akan muncul dibawahnya dan user hanya melakukan kli pada barang yang dipilih, maka barang tersebut akan muncul pada di tampilan pada gambar 12 . 


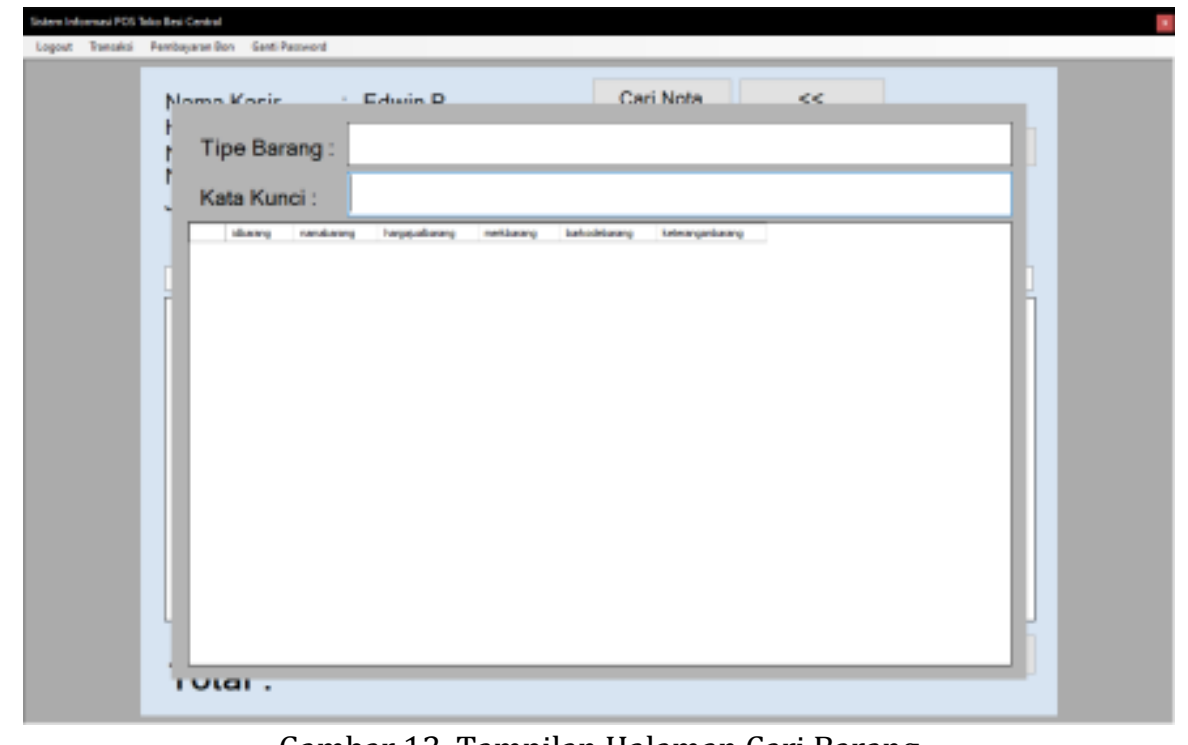

Gambar 13. Tampilan Halaman Cari Barang

Selain itu user harus memasukkan pelanggan jika sudah terdaftar, dengan cara klik tombol "Cari Pelanggan", sehingga akan muncul tampilan seperti pada gambar 14 berikut. Dimana pada gambar 14 tersebut, user dapat dengan mudah mencari pelanggannya dengan mengetikkan pada inputan yang tersedia yang ada pada gambar 14 maka pelanggan yang dicari tersebut akan muncul dibawahnya dan user tinggal melakukan klik untuk memilihnya, dan program akan mengarahkan kembali ke halaman yang ada pada gambar 12 .

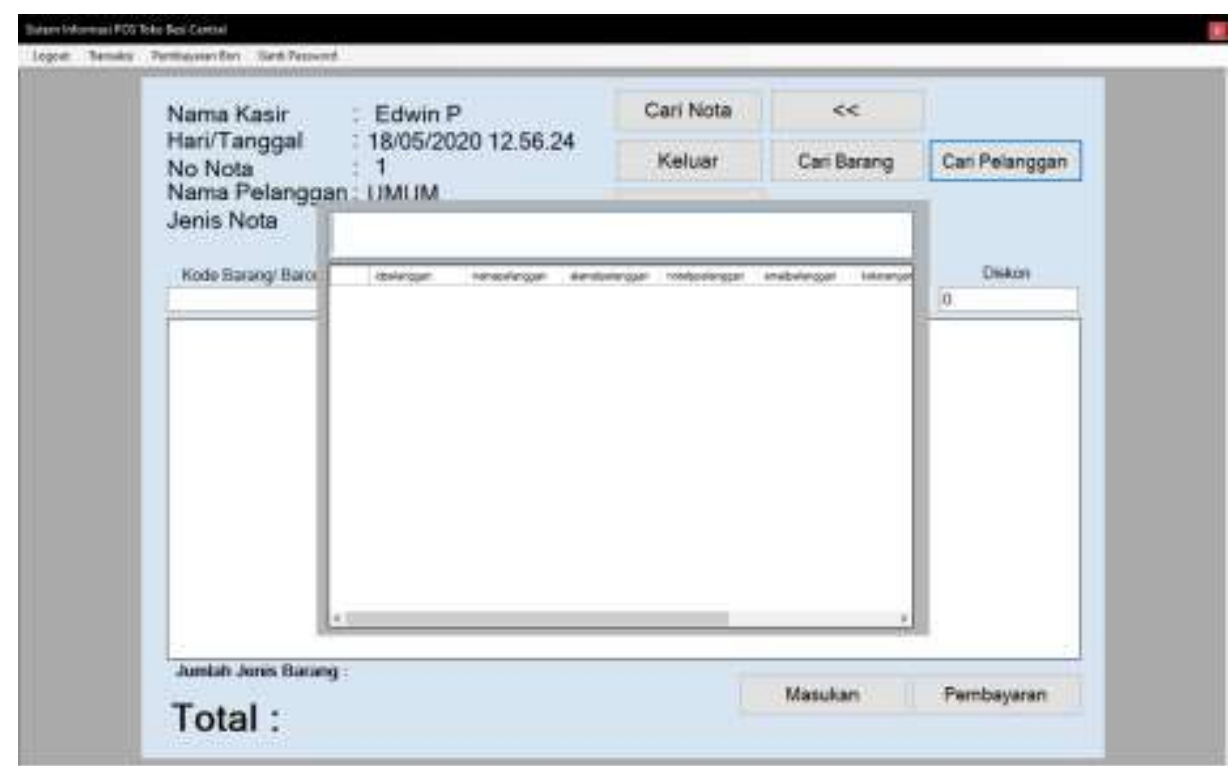

Gambar 14. Tampilan Halaman Cari Pelanggan

Setelah user sudah melakukan inputan barang dan inputan pelanggan, maka selanjutnya user akan melakukan pembayaran dengan cara menekan tombol "Pembayaran" seperti yang tertera pada gambar 15 berikut. 


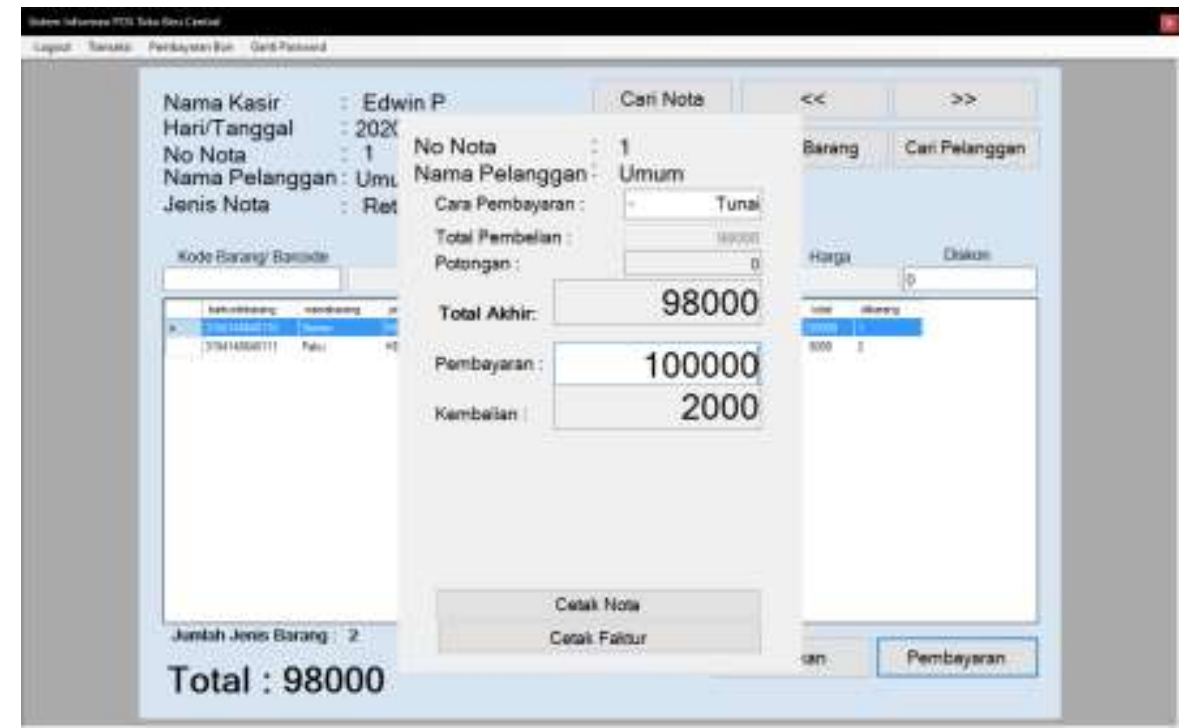

Gambar 15. Tampilan Halaman Pengelolaan Pembayaran

Setelah user sudah melakukan inputan barang dan inputan pelanggan, selanjutnya yang dilakukan user adalah melakukan pembayaran. Pada tampilan yang tertera pada gambar 15 tersebut, user akan memasukkan jumlah pembayaran yang dilakukan oleh pelanggan serta memasukkan cara pembayarannya apakah tunai atau tidak. Setelah inputan pembayaran telah diinputkan user, maka sistem akan secara otomatis menampilkan jumlah kembalian yang harus dikembalikan ke user. Pada tampilan tersebut, terdapat juga 2 tombol yakni tombol cetak nota dan cetak faktur. Dan jika sudah melakukan proses pembayaran ini, maka user dapat menekan tombol "Cetak Nota", sehingga akan muncul seperti pada gambar 16 berikut nota pembayaran yang akan diberikan ke pelanggan.

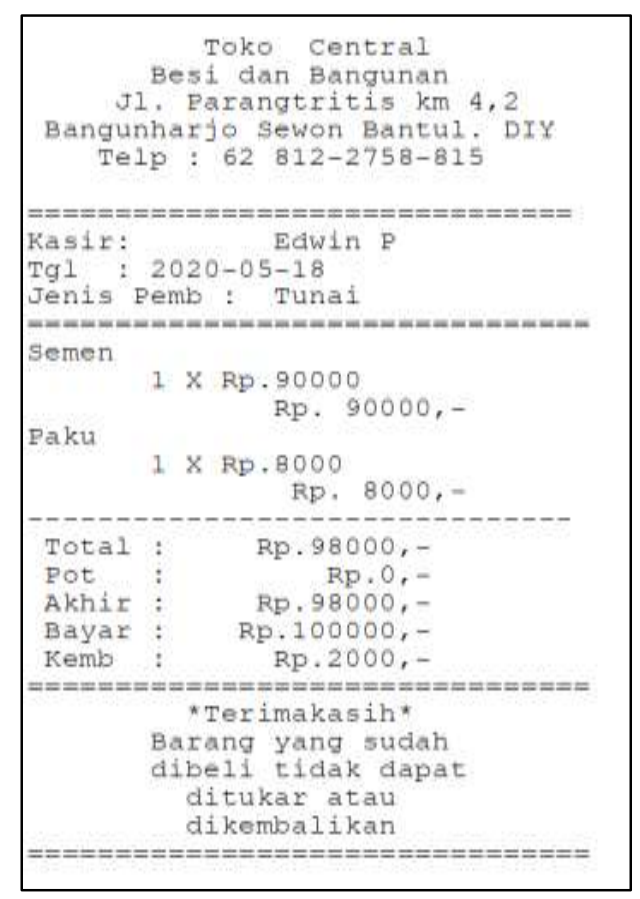

Gambar 16. Tampilan Halaman Hasil Cetak Nota 


\section{B. Pelatihan Penggunaan Aplikasi}

Pelatihan ini dilakukan pada tanggal 21 Februari 2020 untuk pengelola dari Toko Besi dan Bangunan Central Yogyakarta. Tujuannya adalah agar admin dapat selalu melakukan updating informasi yang ada di sistem. Agar dapat mempermudah pemahaman dan praktek dari administrator sistem, tim sudah menyediakan modul penggunaan aplikasi, sehingga dapat digunakan sebagai pentunjuk pengoperasian sistem ini.

\section{KESIMPULAN}

Kegiatan pengabdian pada masyarakat ini telah mencoba untuk memanfaatkan penggunaan sistem informasi sebagai media untuk pengelolaan transaksi bagi Toko Besi dan Bangunan Yogyakarta. Bersama pengelola mitra ini, tim telah bekerjasama untuk membuat sistem berbasis dekstop dan membekali pengelola toko untuk dapat mengelola dan menjalankan sistem informasi tersebut. Harapan selanjutnya tentu saja sistem informasi ini dapat selalu diperbaharui dengan fungsi-fungsi yang menunjang sehingga dapat meningkatkan daya saing dan manajemen transaksi di toko ini.

Keberhasilan dari peningkatan daya saing melalui sistem informasi yang sudah dilakukan, masih membutuhkan waktu untuk dapat diukur seberapa besar keefektivitasannya. Namun setidaknya, pengelola toko sudah dapat mulai mengelola secara komputerisasi baik pelaporan maupun pencatatan datanya.

\section{UCAPAN TERIMA KASIH}

Tim mengucapkan terimakasih atas bantuan dana hibah dari Universitas Atma Jaya Yogyakarta melalui skim Pengabdian Internal Kelompok sehingga kegiatan pengabdian pada masyarakat ini bisa terselenggara dengan baik. Terimakasih juga kami ucapakan atas kerjasama yang menyenangkan serta penuh semangat dari pengelola Toko Besi dan Bangunan Central Yogyakarta

\section{DAFTAR PUSTAKA}

Adithama, S. P., Maslim, M., Harjoseputro, Y., \& Suharno, H. R. (2017). Rancang Bangun Sistem Informasi Manajemen dan Reservasi untuk Rumah Pembinaan. Jurnal Buana Informatika, 8(4), 213-224. https://doi.org/10.24002/jbi.v8i4.1445

Firdaus, D. W., \& Widyasastrena, D. (2017). Perancangan Sistem Informasi Akuntansi Koperasi Dan Umkm Berbasis Technopreneur. Perancangan Sistem Informasi Akuntansi Koperasi Dan Umkm Berbasis Technopreneur, 5(2), 1423-1440. https://doi.org/10.17509/jrak.v5i2.8124

Harjoseputro, Y., \& Herawati, F. A. (2018). Pemanfaatan Website sebagai Media Promosi Kampung Wisata Rejowinangun dan Pakualaman, Yogyakarta. In Prosiding Seminar Nasional Hasil Pengabdian kepada Masyarakat (SENDIMAS) (Vol. 3, hal. 77-82).

Jonathan, W., \& Lestari, S. (2015). Sistem Informasi Ukm Berbasis Website Pada Desa Sumber Jaya. Jurnal Teknologi Informasi dan Bisnis Pengabdian Masyarakat Darmajaya, 1(1), 1-16.

Martinus Maslim, Adithama, S. P., \& Nugroho, A. H. T. (2020). Pembangunan Sistem Informasi Penjualan Pada Usaha Mikro, Kecil, Dan Menengah (Studi Kasus : Pahala Fotokopi dan Digital Printing). Dinamisia: Jurnal Pengabdian Kepada Masyarakat, 4(1), 95-105. https://doi.org/10.31849/dinamisia.v4i1.3363

Mumtahana, Hani Atun, Nita, S., \& Tito, A. W. (2017). khazanah informatika Pemanfaatan Web ECommerce untuk Meningkatkan Strategi Pemasaran. Pemanfaatan Web E-Commerce untuk Meningkatkan Strategi Pemasaran, 3(1), 6-15. Diambil dari http://journals.ums.ac.id/index.php/khif/article/view/3309/2784

Nandan, R. (2010). Management Accounting Needs of SMEs and the Role of Professional 
Accountants: A Renewed Research Agenda. Journal of Applied Management Accounting Research, 8(1), 65-78.

Nugraha, F. (2016). Analisa dan Perancangan Sistem Pemasaran Berbasis E - Commerce Untuk Pemasaran Produk UMKM. Indonesian Journal on Networking and Security, 5(3), 33-37. Diambil dari http://ijns.org/journal/index.php/ijns/article/view/1426/1406

Putu, I. G., \& Aditya, N. (2015). Pengaruh Persepsi Kemudahan Penggunaan Dan Kegunaan Pada Implementasi Sak Etap (Studi Empiris Pada Ukm Di Denpasar Utara). E-Jurnal Akuntansi, 13(3), 857-887.

Rifani, L., \& Aini, N. (2016). Aplikasi sistem informasi akuntansi pada usaha kecil menengah kampung kue rungkut surabaya. In Seminar Nasional Sistem Informasi Indonesia (hal. 427436).

Sinarwati, N. K., Sujana, E., Nyoman, D., \& Herawati, T. (2019). Peran Sistem Informasi Akuntansi Berbasis Mobile Bagi Peningkatan Kinerja Umkm. Jurnal KRISNA: Kumpulan Riset Akuntansi, 11(1), 26-32. https://doi.org/10.22225/kr.11.1.1123.26-32 